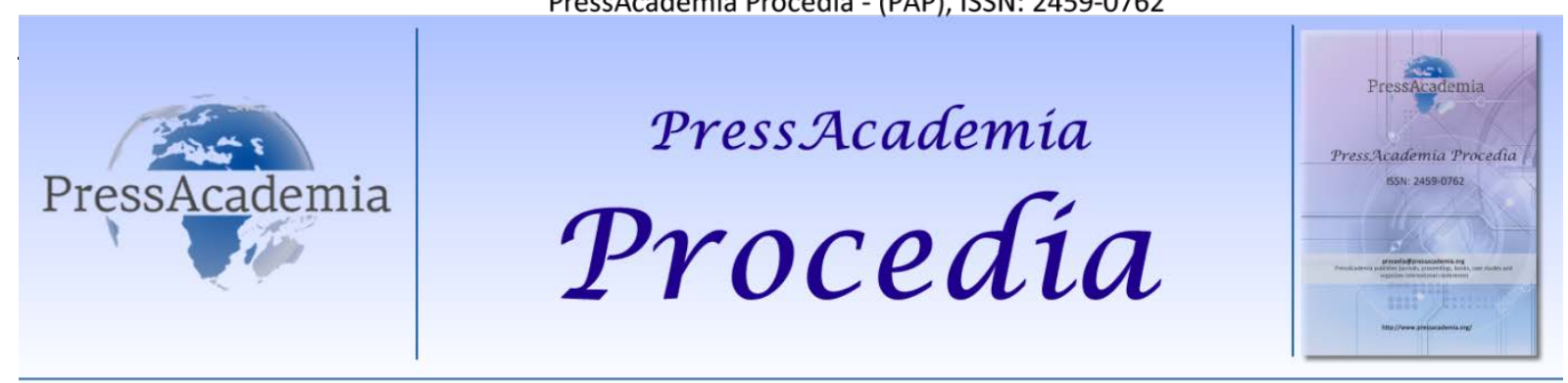

Global Business Research Congress (GBRC), May 26-27, 2016, Istanbul, Turkey.

\title{
FOREIGN OWNERSHIP AND STOCK PRICE SYNCHRONICITY: EVIDENCE FROM TURKEY
}

\section{DOI: 10.17261/Pressacademia.2016118627}

\author{
Oktay Tas ${ }^{1}$, Selin Duz $\operatorname{Tan}^{2}$ \\ ${ }^{1}$ Istanbul Technical University, oktay.tas@itu.edu.tr \\ ${ }^{2}$ Istanbul Technical University, selinduztan@gmail.com
}

\begin{abstract}
This study investigates the impact of foreign ownership structure on the flow of firm specific information to stock prices in Turkey. This paper will be first to examine the relationship between ownership and stock price synchronicity in Turkey. We examine the effects of foreign ownership on the amount of firm specific information incorporated into share prices, as measured by stock price synchronicity, for listed firms in Borsa Istanbul 100 Index over the 2009-2014 period. We support the view that the R squared value in one of the emerging stock markets, Turkey is relatively high. We hypothesize and show that stock price synchronicity is lower for firms which have more foreign ownership ratios. That supports more firm specific information is incorporated into stock prices as the ratio of foreign ownership increases.
\end{abstract}

Keywords: Stock price synchronicity, foreign ownership, foreign shareholders.

JEL Cods: G10; G32

\section{INTRODUCTION}

Foreign shareholders have been described as an important group of investors in emergent financial markets. Foreign direct investment flows to emergent markets have significantly increased in recent years and Turkey has 12.6 billion dollars foreign net direct investments in 2014. Ownership structure has become an important issue in analyzing the efficiency of alternative corporate governance mechanisms in recent years. This study investigates whether foreign owners affect the stock prices incorporate specific information about a firm's fundamental value.

Many studies in the literature focuses on ownership structure and performance. However, few studies examine the synchronicity which shows how much firm specific information that is reflected to stock prices. This paper aims to combine these two areas by examining the impact of ownership structure, change in ownership concentration in explaining the synchronicity of stock price movements.

Roll (1988) states that a large proportion of stock return variation is not explained by announcement of public information or market characteristics. Roll finds adjusted $R$ square is 0.20 with daily data. Built on his view, Morck et al. (2000) examine synchronicity in the world for the countries, and find that stock price movements are more synchronous in emerging markets than developed markets. Other important result shows that greater public investor legal protection leads to higher firm specific returns variation and lower synchronicity. This study is one of the few studies that examine the stock price synchronicity in Turkey and shows that Turkey has one of the five highest synchronicity across other countries. 
Two recent studies are closely associated with our study. Gul et al. (2010) examines the effects of largest shareholder ownership concentration, foreign ownership, and audit quality on stock price synchronicity for Chinese listed firms. Synchronicity is a concave function of ownership by the largest shareholder and foreign ownership is inversely related to synchronicity. According to this study, higher stock price synchronicity or lower firm specific return variation in emerging markets is a result of corporate ownership structure in emerging markets. He et al. (2013) shows large foreign ownership around the world is positively related to probability of informed trading and price non synchronicity that shows firm specific variations in stock returns. They also find out strong relation between stock returns and future earnings innovations for firms with higher foreign ownerships. He and Li emphasizes that stock prices incorporate all information and reflect a firm specific information and value in an efficient market and limits the arbitrage. Thus, stock price synchronicity or price informativeness are important for both financial market actors to corporate decide. He et al. (2013) conclude that foreign shareholders may closely monitor managers and limit agency problems leading to less stock price synchronicity. This study also strengthens the aim of this study with large foreign owners will be less engaged with other domestic holders which leads to enhance the monitoring role of foreign owners. Kho et al. (2009) supports this idea, foreign shareholders could be more effective in monitoring when foreign shareholders come from "good governance" countries and investing in "poor governance" countries.

Ntow et al. (2015) investigates whether corporate governance influence the release of firm specific information. This study uses the determination of synchronicity as an inverse measure of transparency and shows that larger board sizes are associated with high synchronicity and less transparency. Other result depicts that an increase in non-executive directors on corporate boards makes synchronicity lower and increase transparency. This study also analyzes the relation between firm size, type and level of synchronicity. Financial firms exhibit higher levels of synchronicity due to because they make the entire market return in their direction. Larger firms are more synchronous than smaller firms since their market return is highly concentrated with these returns.

According to Chan and Hameed (2006), emerging markets show poor information disclosure and lack of corporate transparency discourages informed trading and decreases the incorporation of firm- specific information into stock prices, which means more stock price synchronicity. And Jin and Myers (2006) demonstrate poor investor protection and opaque financial disclosure increases stock price synchronicity.

Few studies focus on ownership structure and firm specific information or transparency in Turkey. Gursoy and Aydogan (2002) investigate the impact of ownership structure on performance and risk-taking behavior of listed Turkish firms. This study is important to show the impact of ownership concentration and ownership mixon both performance and risk-taking behavior of listed firms in Turkey. The results reveal that concentration is positively related to market performance and firms with foreign ownership perform better. Aksu and Kosedag (2006) score transparency and disclosure scores of 52 large and liquid ISE firms. The study investigates the firmspecific determinants of the transparency and disclosure score and finds out size, accounting profitability and market-to-book ratio explain the differences in the transparency scores, in the ownership and board and management.

Our paper contributes to the literature on the role of foreign ownerships in three ways. First, we document an important relation between stock price synchronicity and firm level corporate governance characteristics or ownership structure in Turkey. Second, our results support the idea one of the emerging markets, Turkey has relatively high $\mathrm{R}$ square value comparatively other developed market $\mathrm{R}$ squared values in recent studies. Third, our results depict the relation between firm level financial ratios such as leverage, profitability, market to book ratio and stock price synchronicity as control variables.

The paper is organized as follows. Section 2 describes data and the construction of key variables. Section 3 reports and discusses the empirical results. And the final section gives conclusions. 


\section{DATA AND CONSTRUCTION OF VARIABLES}

\subsection{Data}

This study contains listed firms in Borsa Istanbul 100 Index between years 2009-2014. 86 firms were analyzed in our sample due to lack of data since 14 firms were listed in Borsa Istanbul after 2009. The firms are included in BIST100 Index as of 30.09.2015. The constituent firms of BIST100 Index are collected from Borsa Istanbul database. Our sample covers daily firm and market level returns and balance sheet data from Reuters database. We hand collect ownership data from firms' annual reports from Public Disclosure Platform.

Table 1 shows the distribution of our sample firms by main industries based on Borsa Istanbul industry classification. Observations concentrates on two main industries: manufacturing (43.02\%) and financial (32.56\%).

Table 1: Sample Distribution

\begin{tabular}{llcccc} 
Industry & & \multicolumn{3}{c}{$\begin{array}{c}\text { Number of } \\
\text { Foreign } \\
\text { Companies }\end{array}$} & $\%$ \\
\hline & $\begin{array}{l}\text { Observations } \\
\text { Education, Sport and }\end{array}$ & $\%$ & & & \\
& Health & 18 & 3,49 & 0 & 0,00 \\
& Electricity, Gas, water & & & & \\
& and Construction & 18 & 3,49 & 6 & 3,46 \\
& Financial & 168 & 32,56 & 27 & 15,60 \\
& Manufacturing & 222 & 43,02 & 103 & 59,53 \\
& Mining & 18 & 3,49 & 0 & 0,00 \\
& Technology & 18 & 3,49 & 12 & 6,93 \\
& Transportation, & & & & \\
& Telecommunication and & & & & 6,93 \\
& Storage & 24 & 4,65 & 12 & 7,51 \\
\hline Wholesale and Retail & 30 & 5,81 & 13 & 100,00 \\
\hline
\end{tabular}

\subsection{Stock Price Synchronicity}

We use the stock price synchronicity initially generated by Roll (1988) and developed by Morck et al. (2000) as a proxy for firm specific information incorporated into share prices. In the literature, synchronicity is generated by the regression's R-squared value of individual stock returns on market and industry indexes. High R-squared level means the firms' stock prices are synchronous with market and/or industry returns which means firm specific information is not included in share prices. Generally, this synchronous behavior is defined as the firms are less transparent since the synchronicity is higher in the literature.

Roll (1988) analyzes stock price synchronicity by adding industry returns to explain stock returns in the regression model. However, Chan and Hameed (2006) support the idea adding industry returns to regression is problematic in emerging markets because in the economy may be dominated by a few industries, thus it is difficult to separate the industry effect from the market effect. In our sample, manufacturing (43.02\%) and financial (32.56\%) sectors have relatively high weights in total, so industry returns are not included in stock price synchronicity model as explanatory variable.

We define stock price synchronicity consistent with the literature as Morck et al. (2000), Gul et al. (2010) as

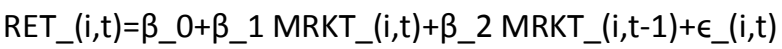

where RET_( $i, t)$ is firm i's return on day $t$, MRKT_(i,t) is the value weighted market return (BIST100 index) for day $t, \epsilon_{-}(i, t)$ represents unspecified random factors. Synchronicity is estimated with split regressions by using 
individual daily stock returns as a dependent variable, the daily market return and lag of daily market return. Industry returns may be added to the regression up to significance of the regression. Some authors in the literature review expresses that adding industry return to the synchronicity regression may cause spurious results. The $\mathrm{R}$ squared result of regression is bounded within unit interval. Then logarithmic transformation of all $R^{\wedge} 2 /\left(1-R^{\wedge} 2\right)$ of the models is computed as Morck et al. (2000) defined. Our dependent variable is defined as

$$
\text { 『SYNCH』_(i,t)=logi:( }\left(R^{\wedge} 2 /\left(1-R^{\wedge} 2\right)\right)
$$

where SYNCH_(i,t) is firm i's stock price synchronicity on year $t, R^{\wedge} 2$ is the regression result of the stock price synchronicity model for firm $\mathrm{i}$ and year $\mathrm{t}$.

\section{Table 2: Descriptive statistics for stock price synchronicity}

Panel A: Stock Price Synchronicity (Year distribution)

Panel B: Stock Price Synchronicity (Industry distribution)

\begin{tabular}{cclc}
\hline Year & Average SYNCH & Industry & Average SYNCH \\
2009 & $-0,4153$ & Education, Sport and Health & $-0,4153$ \\
2010 & $-0,5208$ & Electricity, Gas, water and Construction & $-0,5208$ \\
2011 & $-0,4655$ & Financial & $-0,4655$ \\
2012 & $-0,4694$ & Manufacturing & $-0,4694$ \\
2013 & $-0,3902$ & Mining & $-0,3902$ \\
2014 & $-0,4478$ & Technology & $-0,4478$ \\
& & Transportation, Telecommunication and Storage & $-0,3655$ \\
& & Wholesale and Retail & $-0,5267$ \\
\hline
\end{tabular}

Table 2 shows descriptive statistics for each year and for each industry. The highest level of stock price synchronicity is in 2013 and the lowest level is in 2010. The second part of table shows financial sector has the highest level of stock price synchronicity. Transportation, Telecommunication and Storage is the second sector. Panel A shows the distribution of sample firms across years and Panel B shows the distribution of sample firms across industries. based on the categories issued by Public Disclosure Platform.

\subsection{Ownership Structure Variable}

Ownership structure variable in this study is defined as the ratio of foreign ownership. Our sample consists of foreign ownership, $34 \%$ of total observations. Only 10 observations are less than $5 \%$, thus we can support the idea this study investigates the effect of large foreign shareholders as He et al. (2013) defines large foreign shareholder as ultimate owners who own more than $5 \%$. Table 3 demonstrates that average foreign ownership ratio is highest in 2010 and lowest in 2013. This is a remarkable result considering the opposite results shown in Table 2, highest level of stock price synchronicity is in 2013 and the lowest level is in 2010. In industry basis, Education, Sport and Health and Mining sectors do not have any foreign owners. Highest foreign ownership ratio is in technology sector with $38,62 \%$ followed by Wholesale and Retail, $21.42 \%$.

Table 3: Descriptive statistics for foreign ownership

Panel A: Foreign Ownership Ratio (Year distribution) Panel B: Foreign Ownership Ratio (Industry distribution)

\begin{tabular}{|c|c|c|c|}
\hline Year & Average Foreign Ownership & Industry & Average Foreign Ownership \\
\hline 2009 & Educati & , Sport and Health & 0,0000 \\
\hline 2010 & Electrici & , Gas, water and Construction & 0,1245 \\
\hline 2011 & Financia & & 0,0484 \\
\hline 2012 & Manufa & uring & 0,1733 \\
\hline 2013 & Mining & & 0,0000 \\
\hline \multirow[t]{3}{*}{2014} & Technol & & 0,3862 \\
\hline & Transpo & tation, Telecommunication and Storage & 0,1702 \\
\hline & Wholes & e and Retail & 0,2142 \\
\hline
\end{tabular}


Panel A shows the distribution of firms with foreign ownership across years and Panel B shows the distribution of firms with foreign ownership across industries based on the categories issued by Public Disclosure Platform.

Figure 1 depicts the relation between stock price synchronicity and the percentage of shareholdings by foreign owners. To examine the detailed association between foreign ownership and synchronicity, we compare the average stock price synchronicity levels in different foreign shareholding intervals: 0-20\%, 20-40\%, 40-60\%, 60$80 \%$ and $80-100 \%$. This figure reveals that stock price synchronicity significantly decreases as the percentage of shareholdings by foreign owners increases.

\subsection{Control variables}

We define our control variables as trading volume, age (the logarithm of years after IPO of the firm), firm size (log of total assets), leverage (total liabilities divided by total assets), earning volatility, the standard deviation of ROA-return on assets (volatility of firm's earnings over the preceding five-year period including the current year) and market to book ratio (the total market value of equity divided by the total net assets).

Figure 1: Foreign owners and stock price synchronicity

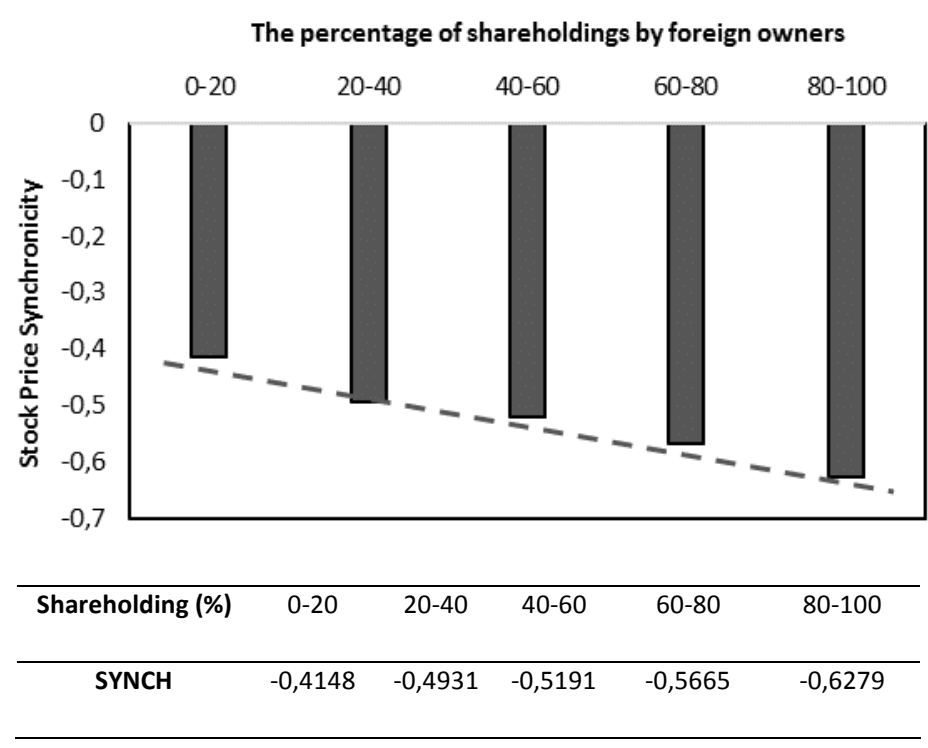

The level of AGE shows number of years that have passed after firm initial publicly offered. AGE increases while firm becomes older, and the market learns more about time-invariant firm characteristics or firm specific information as Dasgupta et al. (2010) emphasized. Thus stock return synchronicity should be higher for older firms. The logarithm of AGE is taken as a consistent with literature and avoid unit root data problems. The leverage ratio, LEV, shows total liabilities divided by total assets in a firm level. Hasan and Song (2014) supports that Leverage and stock price synchronicity have positive relation since the cost of collecting private information will be higher with greater risk of financial difficulties or leverage. The market to book ratio, MBRAT, shows the total market value of equity divided by the total net assets. As Hasan et al. (2014) stated, market to book ratio is negatively related to stock price synchronicity, expected to be negative because higher growth potential firms are likely to incorporate more firm-specific information which means less stock price synchronicity. The SIZE, the logarithm of total assets and shows the size of the firm. BIST 100 index is used as a market return indicator in stock price synchronicity regression model. As BIST 100 index is generated by value weighted and large firms, large companies may dominate market movements. So we expect a positive relation between stock return synchronicity and the size of a company. Earning volatility, STDROA, shows the standard deviation of ROA-return on assets (volatility of firm's earnings over the preceding five-year period including the current year). The relation between earning volatility and stock price synchronicity is expected s negative because higher earning uncertainty will lead more firm-specific variation as Gul et al. (2010) stated in their 
study. The level of VOL, trading volume of stocks influences the speed of price adjustments, thus stocks that have more volume react to market information immediately. This leads to these stocks prices will be more synchronous with market prices. (Chan and Hameed, 2006).

Table 4: Model variable definitions

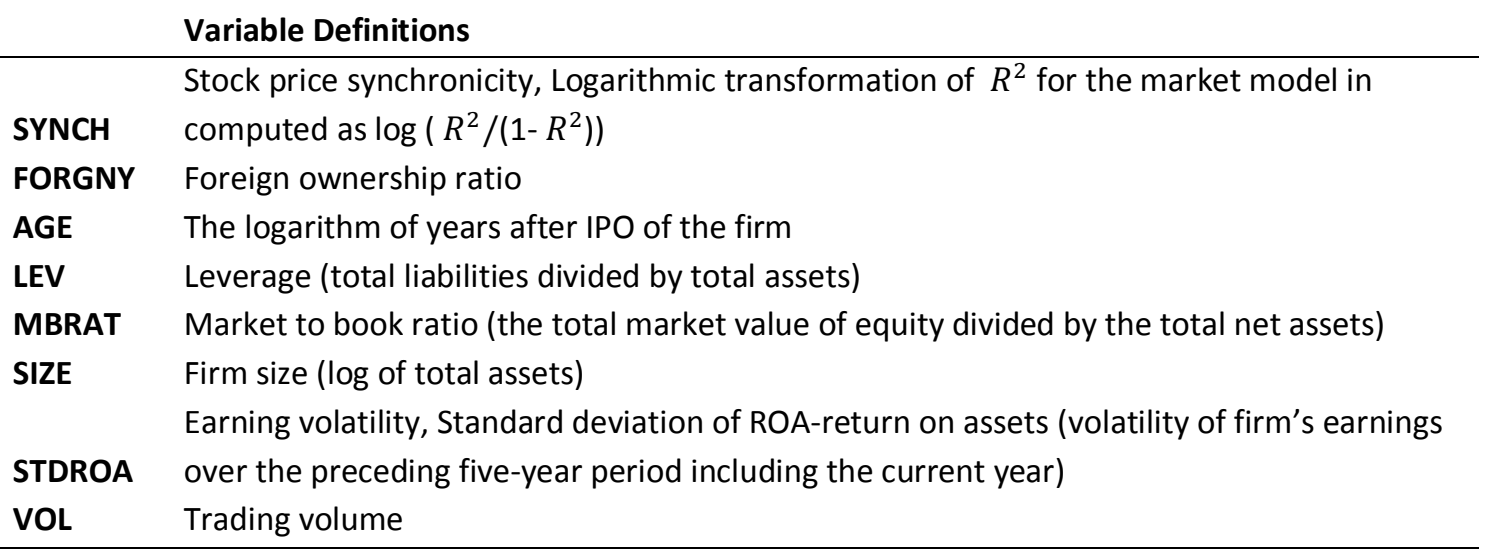

\subsection{Descriptive Statistics}

Descriptive statistics shows that the reported mean $R^{2}$ of 0.393 for Turkey and Morck et al. (2000), Turkey is one of the five highest $R$ squared countries in this study. Standard deviation of synchronicity is 0.505 that shows the flow of firm-specific information to the market changes across firms in a wide range. Descriptive statistics, table 5 , also shows the mean of foreign ownership ratio is 0.12 . Pair wise correlations between our dependent, independent and control variables show synchronicity is negatively correlated with foreign ownership, FORGNY consistent with our hypothesis.

Table 5: Descriptive Statistics

\begin{tabular}{llllllllll} 
& \multicolumn{1}{c}{$\boldsymbol{R}^{\mathbf{2}}$} & SYNCH & FORGNY & MBRAT & VOL & STDROA & SIZE & AGE & LEV \\
\hline Mean & 0,305 & $-0,4515$ & 0,1285 & 1,7455 & 1490 & 0,0517 & 9,3748 & 16,1046 & 0,5479 \\
Median & 0,2854 & $-0,3984$ & 0,0000 & 1,2367 & 386 & 0,0338 & 9,3013 & 16,0000 & 0,5192 \\
Maximum & 0,853 & 0,7637 & 0,9550 & 18,1301 & 21000 & 0,4974 & 11,4405 & 40,0000 & 4,4789 \\
Minimum & 0,0024 & $-2,6177$ & 0,0000 & $-19,3651$ & 957871 & 0,0005 & 7,6766 & 0,0000 & 0,0018 \\
Std. Dev. & 0,1927 & 0,5052 & 0,2383 & 2,4993 & 2680 & 0,0648 & 0,8011 & 7,8143 & 0,4083 \\
\hline
\end{tabular}

\subsection{Model}

This study covers six-year data of 86 listed firms and has panel data feature. In this study, time series linear regression is used to compute $\mathrm{R}$ squared values of all individual firms and panel regression model is used to combine all variables. The model is used to examine the effect of foreign ownership and control variables on stock price synchronicity:

$$
S Y N C H_{i, t}=\beta_{0}+\beta_{1} \text { FORGNY }_{i, t}+\beta_{2} \text { Control }_{i, t}+\epsilon_{i, t}
$$

where $S Y N C H_{i, t}$ is firm i's stock price synchronicity on year t, FORGNY $Y_{i, t}$ is firm i's foreign ownership ratio on year $\mathrm{t}$, Control $_{i, t}$ is firm i's control variables on year $\mathrm{t}$. 


\section{FINDINGS AND DISCUSSIONS}

Panel data using may cause spurious regression problems if data has unit root. To prevent misleading model solutions, unit root tests should be done for all variables. PP Fisher Chi square and LLC tests results are considered to have balanced panel data results.

Table 6 shows unit root test results and the results demonstrate that all variables are stationary. The null hypothesis which states there is a unit root is rejected in 0.01 confidence interval for all variables. Hausman test is performed to decide fixed or random cross section model is used. Hausman test results show that $p$ values are less than 0.05 and we cannot reject the hypothesis model will be random effect. Fixed models for all three models are used.

Table 6: Unit root test results

\begin{tabular}{lcccc} 
& \multicolumn{2}{c}{ Levin, Lin\&Chu t } & \multicolumn{2}{c}{ PP Fisher Chi-square } \\
& probability & t statistics & probability & t statistics \\
\hline SYNCH & 0.0000 & -42.4062 & 0.0000 & 513.613 \\
FORGNY & 0.0000 & -84.8787 & 0.0017 & 52.2716 \\
LOGAGE & 0.0000 & -16.9594 & 0.0000 & 370.122 \\
LEV & 0.0000 & -39.0423 & 0.0000 & 331.295 \\
MBRAT & 0.0000 & -41.3651 & 0.0000 & 417.707 \\
SIZE & 0.0006 & -3.2524 & 0.0003 & 243.229 \\
STDROA & 0.0000 & -1772.61 & 0.0033 & 234.776 \\
VOL & 0.0000 & -33.8224 & 0.0000 & 308.155 \\
\hline
\end{tabular}

Hausman test results show fixed effect model is chosen rather than random effect model because probability level is less than 0.005 and we reject the null hypothesis that states the effect of firms used in the model and time is random, and there is no correlation between error terms and explanatory variables. Conversely, we accept the hypothesis states that the effect of the firms used in the model and time is fixed and there is a correlation between error terms and explanatory variables.

One of the main assumption of regression analysis is that no relationship between error term, autocorrelation. For panel data, residual cross section dependence tests are performed. The results for all three model shows that there are serial correlations between error terms, autocorrelation problems.

Autocorrelation test results indicate that we reject the hypothesis no cross section dependence or correlation in residuals. This results show that we face with autocorrelation problems in residuals. To solve the autocorrelation and heteroscedasticity problems, White period standard errors and covariance method is used and the final model results are obtained.

Table 7 reports regression results for the model to examine foreign ownership structure and stock price synchronicity. As seen in model results column, the coefficient of FORGNY which shows foreign ownership ratio is significantly negative (-0.3844). This suggests that to have foreign ownership in the firm ownership structure will decrease stock price synchronicity and make the firm specific information more incorporated into share prices. This result supports the discussion in the literature, large foreign ownership is positively related to nonstock price synchronicity or price informativeness. Foreign shareholders improve price informativeness through their informed trading and improve corporate governance and disclosure quality of the invested firms which leads to decrease stock price synchronicity (He et al., 2013). The table additionally reports the significancy results of control variables. LOGAGE coefficient is significant positive supporting that older firms tend to learn about time-invariant information and synchronicity is significantly higher for firms that have been listed before other firms (Dasgupta et al., 2010). The MBRAT coefficient is significantly negative (probabilities are 0.0000 ) for the model. This suggests that firms with high growth potential tend to have less stock price synchronicity and more firm-specific information incorporated into their stock prices. The LEV coefficient is significantly positive. This shows that stock prices of more leveraged firms listed in Borsa Istanbul 100 index 
tend to have more synchronous behavior than other small firms. VOL coefficients are significantly positive and supports the result of large firms that have more trading volume will be more synchronous. The other coefficient estimates of control variables are insignificant in all regressions.

\begin{tabular}{lccc} 
Variable & \multicolumn{3}{c}{ Table 7: Model panel regression results } \\
Model Results & Variable & Model Results \\
\hline FORGNY & -0.3844 & SIZE & -0.0573 \\
& $(-2.8727)$ & & $(-0.6364)$ \\
LEV & 0.3306 & STDROA & -1.2497 \\
& $(3.7862)$ & & $(-1.8162)$ \\
LOGAGE & 0.4789 & VOL & $3.84 \mathrm{E}-11$ \\
& $(2.0343)$ & & $(3.6209)$ \\
MBRAT & -0.0375 & SIZE & -0.0573 \\
& $(-3.7160)$ & & $(-0.6364)$ \\
N & 514 & C & -0.5144 \\
Adj. R2 & 0.4786 & & $(-0.7378)$ \\
\hline *The effect of foreign ownership on stock price synchronicity. SYNCH: \\
Dependent variable. Numbers show coefficients of all variables in the \\
model and numbers in parentheses represent t-values. * Cross section \\
fixed, period fixed. ** White cross section standard errors\&covariance (d.f. \\
corrected) \\
\hline
\end{tabular}

\section{CONCLUSION}

We investigate the impact of foreign ownership ratio on stock price synchronicity in Turkey. We support the view that the $\mathrm{R}$ squared values in emerging stock market are relatively high and changes in stock prices in the market do not reflect firm-specific information not as in developed markets. We show there is a negative relation between synchronicity and foreign ownership: as foreign ownership increases, synchronicity decreases. That supports more firm-specific information is incorporated into stock prices as the ratio of foreign ownership increases. We also find market to book ratio is negatively related to stock price synchronicity, supporting high growth potential tend to have less stock price synchronicity. Number of years passed after initial public offering has significantly positive coefficient, synchronicity is significantly higher for firms that have been listed before other firms. Volume and leverage are also positively related to stock price synchronicity which leads to firms that have more leverage and trade volume have more synchronous behavior than other firms. The results of this study leads to encourage foreign ownership in firm level corporate governance that improves the information environment in emerging countries as Turkey. This study only focuses in the firms listed in Borsa Istanbul 100 Index. Further, all listed firms could be examined and industry level analysis could be added to this study.

\section{REFERENCES}

Agung, I. G. N. 2013," Panel Data Analysis Using EViews", Wiley: pp. 123-135.

Aksu, M., Kosedag, A. 2006, "Transparency and Disclosure Scores and Their Determinants in the Istanbul Stock Exchange", Corporate Governance: An International Review, vol. 14, no. 4, pp. 277-296.

Central Bank of the Republic of Turkey, December 2014, "International Investment Position Report".

Chan, K., Hameed, A. 2006, "Stock Price Synchronicity and Analyst Coverage in Emerging Markets", Journal of Financial Economics, vol. 80, no.1, pp. 115-147.

Dasgupta, S., Gan, J., Gao, N. 2010, "Transparency, Price Informativeness, and Stock Return Synchronicity: Theory and Evidence", Journal of Financial and Quantitative Analysis, vol. 45, no. 5, pp. 1189-1220. 
Demirag, I., Serter, M. 2003, “Ownership Patterns and Control in Turkish Listed Companies", Corporate Governance: An International Review, vol. 11, no. 1, pp. 40-51.

Farooq, O., Ahmed, S. 2014, "Stock Price Synchronicity and Corporate Governance Mechanisms: Evidence from an Emerging Market", International Journal of Accounting, Auditing and Performance Evaluation, vol. 10, no. 4, pp. 395-409.

Feng, X., Hu, N., Johansson, A. 2015, "Ownership, Analyst Coverage, and Stock Synchronicity in China", Stockholm China Economic Research Institute, Stockholm School of Economics, no. 2015-36.

Gul, F. A., Kim, J. B., Qiu, A. A. 2010, “Ownership Concentration, Foreign Shareholding, Audit Quality, and Stock Price Synchronicity: Evidence from China", Journal of Financial Economics, vol. 95, no. 3, pp. 425-442.

Gürsoy, G., Aydoğan, K. 2002, “Equity Ownership Structure, Risk Taking, and Performance: An Empirical Investigation in Turkish Listed Companies", Emerging Markets Finance \& Trade, 6-25.

Hasan, I., Song, L., Wachtel, P. 2014, “Institutional Development and Stock Price Synchronicity: Evidence from China”, Journal of Comparative Economics, vol. 42, no. 1, pp. 92-108.

He, W., Li, D., Shen, J., Zhang, B. 2013, “Large Foreign Ownership and Stock Price Informativeness Around the World", Journal of International Money and Finance, vol. 36, pp. 211-230.

Jensen, M. C., Meckling, W. H. 1976, "Theory of the Firm: Managerial Behavior, Agency Costs and Ownership Structure", Journal of Financial Economics, vol. 3, no. 4, pp. 305-360.

Jin, L., Myers, S. C. 2006, “R 2 Around the World: New Theory and New Tests”, Journal of Financial Economics, vol. 79, no. 2, pp. 257-292.

Kho, B. C., Stulz, R. M., Warnock, F. E. 2009, "Financial Globalization, Governance, and the Evolution of the Home Bias”, Journal of Accounting Research, vol. 47, no. 2, pp. 597-635.

Morck, R., Yeung, B., Yu, W. 2000, "The Information Content of Stock Markets: Why do Emerging Markets Have Synchronous Stock Price Movements?", Journal of Financial Economics, vol. 58, no.1, pp. 215-260.

Ntow-Gyamfi, M., Bokpin, G. A., Gemegah, A. 2015, "Corporate Governance and Transparency: Evidence from Stock Return Synchronicity", Journal of Financial Economic Policy, vol. 7, no. 2, pp. 157-179.

Piotroski, J. D., Roulstone, D. T. 2004, "The Influence of Analysts, Institutional Investors, and Insiders on the Incorporation of Market, Industry, and Firm-specific Information into Stock Prices", The Accounting Review, vol. 79, no. 4, pp. 1119-1151.

Roll, R. 1988, "R2", Journal of Finance 25, pp. 545-566. 